\title{
O Ateísmo Francês Contemporâneo: uma comparação crítica entre Michel Onfray e André Comte-Sponville Contemporary French Atheism: a Critical Comparison between Michel Onfray and André Comte-Sponville
}

\author{
Agnaldo Cuoco Portugal* \\ Abraão Lincoln Ferreria Costa**
}

\begin{abstract}
Resumo
Michel Onfray e André Comte-Sponville são os dois mais famosos representantes do ateísmo filosófico francês contemporâneo, que continua uma tradição iniciada no século XVIII de negação irreligiosa da noção monoteísta de Deus. Embora compartilhando várias ideias, como o naturalismo e, obviamente, a rejeição do monoteísmo, suas propostas têm diferenças importantes. Onfray imputa à religião a maioria dos males enfrentados pela humanidade, recusando-se a fazer qualquer concessão à tradição religiosa monoteísta, e propondo uma filosofia libertária de tipo hedonista e materialista. Comte-Sponville vê aspectos positivos na religião no tocante à manutenção da unidade social e propõe uma espiritualidade mística ateia. $\mathrm{O}$ artigo faz uma breve apresentação de suas teses e formula críticas a ambas as propostas. Onfray está muito mais preocupado em convencer de uma proposta política do que em argumentar filosoficamente em favor de uma tese e Comte-Sponville não parece perceber as consequências auto-refutadoras do naturalismo, que também torna muito problemática a própria noção de moralidade.
\end{abstract}

Palavras-chave: Michel Onfray; Comte-Sponville; ateísmo; neoateísmo; naturalismo.

\begin{abstract}
Michel Onfray and André Comte-Sponville are the most famous representatives of philosophical contemporary French atheism, which is a continuation of a tradition begun in the $18^{\text {th }}$ Century of irreligious denying of the monotheistic notion of God. Although sharing many ideas, like naturalism and, obviously, the rejection of the monotheistic conception of God, their proposals show important distinctions. Onfray blames on religion most of evils faced by humanity, refusing to make any concession to monotheism, and proposing a libertarian, hedonistic, materialistic philosophy. Comte-Sponville sees positive aspects in religion regarding the keeping of social unity, and puts forward an atheistic spirituality. The article makes a brief presentation of both theses and formulates criticisms to each of them. Onfray is much more concerned with convincing of a political proposal than with arguing in favour of his thesis philosophically, and Comte-Sponville does not seem to notice the self-defeating consequences of naturalism, which also makes very problematic the very notion of morality.
\end{abstract}

Keywords: Michel Onfray; Comte-Sponville; atheism; neoatheism; naturalism.

\footnotetext{
Artigo recebido em 15 de setembro de 2010 e aprovado em 17 de dezembro de 2010.

* Doutor em filosofia da religião pelo King's College da Universidade de Londres, professor do Departamento de Filosofia da UnB. País de origem: Brasil. E-mail: agnaldocp@unb.br

${ }^{* *}$ Mestre em filosofia pela UnB. País de origem: Brasil. E-mail: abraaofilosofia@ gmail.com
} 


\section{Introdução}

Em um sentido estrito, o ateísmo filosófico é um fenômeno novo na história da filosofia. Apesar de atomistas como Epicuro e Lucrécio terem manifestado um tipo de rejeição mais global à noção de divindade e apresentado críticas à religião, o mais comum até antes do século XVIII era o ateísmo como rejeição de uma concepção de deus em favor de um modo mais adequado e verdadeiro de se compreender Deus. Esse ateísmo em sentido amplo, que não nega toda e qualquer forma de Deus e de prática religiosa, é uma posição muito mais tradicional na filosofia e mesmo no diálogo entre as religiões.

No século XVIII, porém, com os materialistas franceses, o ateísmo filosófico estrito ganha um novo destaque na história do pensamento ocidental. Aproveitando o sucesso das ciências naturais na explicação e domínio do mundo, e exprimindo em termos mais rigorosos a insatisfação política com o regime absolutista e seu apoio nas instituições religiosas, o ateísmo manifesta, a partir de então, uma proposta de pura e simples rejeição da religião e da crença num poder transcendente, com base em duas ordens distintas, embora complementares, de argumento. De um lado, argumenta-se contra a crença em Deus por estar esta para além da possibilidade de investigação empírica, sendo, portanto, irracional segundo uma visão científica de mundo. Por outro lado, argumenta-se contra a religião por ser ela fonte de intolerância e um tradicional apoio aos poderes autoritários constituídos ao longo da história humana.

O século XXI, diferente do que Freud indicava em seu famoso texto "O Futuro de uma Ilusão", não viu a religião e a crença em Deus desaparecerem. Ao contrário, segundo a avaliação de muitos, vê-se um retorno da religião à esfera pública e um reforço da crença religiosa em muitas sociedades e meios culturais que pareciam irreversivelmente secularizados.

Em parte como reação a essa possível "onda neoreligiosa", a religião voltou a ser tema importante de autores filosóficos franceses, que haviam se dedicado, no século XX, a temas de ontologia e, principalmente, de filosofia política e ética, entendendo ser a religiosidade uma questão cada vez menos importante na modernidade. Dentre esses pensadores que dão destaque ao tema da religião no cenário filosófico francês 
contemporâneo, não se pode deixar de mencionar Michel Onfray e André Comte-Sponville, autores de verdadeiros best-sellers como Traité d'Athéologie e L'esprit de L'athéisme, respectivamente, rapidamente traduzidos para o português e tendo no Brasil também obtido larga vendagem. São essas as obras centrais na reflexão a ser feita aqui.

No presente artigo, pretende-se analisar as ideias desses dois autores de forma comparativa, tentando entender melhor a proposta e a propriedade das teses apresentadas por eles como parte da filosofia da religião contemporânea, sem deixar de propor críticas a suas considerações.

\section{Onfray e o ateísmo pós-cristão}

Michel Onfray elaborou seu pensamento e ficou famoso como filósofo fora do meio acadêmico instituído, contra o qual se rebelou e fundou uma universidade popular como resposta. Sua ateologia é parte de um projeto de "filosofia libertária", que inclui também a defesa do hedonismo em ética, do materialismo em ontologia e do anarquismo em filosofia política.

Onfray entende que a religião é, ao mesmo tempo, um atentado à inteligência, um sinal de imaturidade psicológica e uma falta de coragem de enfrentar a realidade. Ela procede de uma pulsão de morte, que rejeita tudo que é racional, livre, vivo, feminino e corpóreo (ONFRAY, 2005, p. 103). Ao falar de mundo para além do material, a religião se mostra um obstáculo para a emancipação humana. Ele não despreza o crente, mas denuncia os criadores de fábula, que pretendem satisfazer a vontade de crer:

\footnotetext{
Mas, por toda parte, constatei o quanto os homens fabulam para evitar encarar a realidade de frente. A criação de mundos ideais não seria tão grave se por ela não se pagasse um preço alto: o esquecimento do real e, portanto, a negligência culpável do único mundo que há. Quando a crença briga com a imanência, então ele, o ateísmo, reconcilia com a terra, o outro nome da vida (ONFRAY, 2005, p. 23. Tradução nossa).
}

O estilo e as ideias lembram muito as críticas de Nietzsche ao cristianismo. Onfray reconhece a influência e chega a se declarar um "nietzscheano de esquerda", mas rejeita a tese de que Deus morreu, pois "uma ficção não morre" (ONFRAY, 2005, p. 40). Seu 
ateísmo pretende ir além do deísmo dos iluministas ou das concepções alternativas de Deus de autores como Spinoza. Onfray considera que somente com o ateísmo denominado póscristão ou pós-moderno é possível pensar num ateísmo autêntico, desvinculado de qualquer tradição religiosa. Com essa nova ideologia, o indivíduo poderia deslocar inteligentemente as bases da moralidade e da política para uma nova perspectiva não niilista, mas, segundo o filósofo, apenas pós-cristã. O ateísmo seria a esperança do futuro, a vitória da filosofia racional contra a religião fabuladora (ONFRAY, 2005, p. 70-1).

Essa luta pelo ateísmo autêntico não é nada fácil, pois a cultura ainda parece muito dominada pela visão de mundo cristã. É por essa razão que não se encontram edições críticas, trabalhos acadêmicos ou versões populares de autores ateus como d'Holbach, Helvétius La Mettrie ou Feuerbach. Para Onfray, existe uma notória má vontade do meio acadêmico oficial contra o ateísmo estrito (ONFRAY, 2005, p. 61). Uma má vontade com ares de conspiração, pois é herdeira da perseguição sofrida pela filosofia materialista desde os tempos de Epicuro e do atomismo antigo por parte do Cristianismo (ONFRAY, 2005, p. 128). Para ele, é preciso mudar isso e investir contra o monoteísmo e tudo o que ele representa de mal.

A ateologia onfraryana não busca eliminar os conceitos de bem e de mal. Para o filósofo, há que serem admitidas essas noções conforme o juízo da razão, desprovidas de roupagens religiosas imaginárias, baseadas em concepções sobre o além-mundo. Onfray acredita que a solução para uma moral racional estaria num contrato hedonista. Por meio desse novo pacto social, desenvolver-se-iam novos princípios, fundados no respeito à utilidade e à felicidade do maior número possível de pessoas. Nessa sugestão imanentista, afirma, ocorreria a legitimação de toda intersubjetividade, por meio da liberdade de ação e de pensamento, desvinculando-se das imposições de uma ontologia da recompensa e da punição, pressuposta nas religiões monoteístas.

Nota-se, nessa proposta, significativa influência da deontologia de Jeremy Bentham ou do utilitarismo de Stuart Mill, que o autor aceita de bom grado, uma vez que partem do homem concreto, de carne e osso, e se voltam para um conceito de bem discernível racionalmente, eliminando e influência monoteísta também na ética.

Assim, o Tratado de Ateologia destina-se à missão de justificar a desconstrução dos três grandes monoteísmos; desmitificar a ideologia judeu-cristã, imposta, segundo Onfray à 
cultura ocidental, juntamente com o islã, para então completar a terceira tarefa de desmontar a teocracia. Segundo ele, essa forma de dominação é vista em diferentes tipos de organização política, inclusive na própria democracia.

A teocracia encontra remédio na democracia: o poder do povo, a soberania imanente dos cidadãos contra o pretenso magistério de Deus, de fato daqueles que o reclamam para si... Em nome de Deus, a História testemunha, os três monoteísmos fazem correr rios de sangue durante séculos! Guerras, expedições punitivas, massacres, assassínios, o colonialismo, etnocídios, genocídios, Cruzadas, Inquisições, hoje o hiperterrorismo planetário... (ONFRAY, 2005, p. 97) ${ }^{1}$

Para esse filósofo francês, vivemos numa era niilista, entre a cultura judaico-cristã ainda muito presente e a cultura pós-cristã, que se anuncia modestamente, mas ainda não chegou plenamente (ONFRAY, 2005, p. 76). Curiosamente, também na proposta de Onfray, é no futuro que está a esperança..

Ao abolir qualquer influência cultural e ideológica dos três grandes monoteísmos, o indivíduo obteria condições de produzir uma nova ordem ética, pautada numa moral póscristã, onde o corpo tornar-se-ia um instrumento de afirmação e não do pecado, e onde a política poderia ser a construção da liberdade e não a justificação da tirania.

Onfray (2005, p. 103) acusa as religiões de propagarem o ódio a tudo aquilo que expresse vida e prazer. Seguindo a compreensão do filósofo, o monoteísmo, ao professar uma ontologia da recompensa, acaba colocando o mundo em um vale de lágrimas. A justificativa estaria numa doutrina que considera a felicidade um estado que deve apenas ser adquirido no além-mundo, cabendo, portanto, negar a todo o momento o corpo, as mulheres, a inteligência - possíveis inferências para o pecado.

Não é por menos que Onfray não mostra nenhuma tolerância em relação às religiões monoteístas, especialmente ao cristianismo, pois é a elas que devemos os principais males do mundo há séculos, como vimos acima: escravidão, opressão, guerra, tirania e

\footnotetext{
${ }^{1}$ La théocracie trouve son remede dans la démocratie: le pouvoir du peuple, la souveraineté immanente des ctoyens contre le pretendu magistère de Dieu, en fait de ceux qui s'en réclament... Au nom de Dieu, l'Histoire témoigne, les trois monothéismes font couler pendant des siècles d'incroyables fleuves de sang! De guerres, des expéditions punitives, des massacres, des assassinats, du colonialisme, des ethnocides, des génocides, des Croisades, des Inquisitions, aujourd'hui l'hyperterrorisme planétaire...
} 
obscurantismo (ONFRAY, 2005, p. 251). Contra isso, é preciso uma posição estritamente sem espaço para qualquer traço religioso. Para Onfray,

[...] para defender os valores do Iluminismo contra as proposições mágicas, é preciso promover uma laicidade pós-cristã, a saber, atéia, militante e radicalmente oposta a toda escolha da sociedade entre o judaico-cristianismo ocidental e o islã que ele combate. Nem a Bíblia nem o Corão. Aos rabinos, aos padres, aos imãs, aiatolás e outros mulás, eu insisto em preferir o filósofo. (ONFRAY, 2005, p. 281)2.

É por isso que ele se opõe a formas brandas de ateísmo, tal como a proposta por Comte-Sponville. A crítica de Onfray a seu compatriota se insere na distinção que ele faz entre o ateísmo pós-cristão que ele propõe e outros tipos de ateísmo.

Numa afirmação no mínimo difícil de conciliar com a última citação feita acima, Onfray (2005, p. 90) acredita que somente com aquilo que Deleuze denomina "ateísmo tranquilo" é possível inserir em qualquer sociedade uma ética pós-cristã, verdadeiramente laica. Tratar-se-ia de um procedimento dinâmico, mais preocupado com a afirmação do corpo e da imanência, do que, segundo ele, com a negação combativa de Deus.

Outro posicionamento a ser evitado é a "estranha quimera" do "ateísmo cristão". O filósofo entende por ateísmo cristão uma proposta que ao mesmo tempo defende princípios materialistas e uma ética cristã, tal como o faz André Comte-Sponville em sua defesa ao mesmo tempo do epicurismo e de virtudes enaltecidas pelo cristianismo como o amor ao próximo, a humildade e o desinteresse por bens materiais. Entretanto, o pensamento filosófico desse autor, segundo Onfray, desmerece o real sentido do termo ateísmo, pois permanece integrado a uma moralidade cristã.

Para Onfray, não é possível dissociar a moralidade cristã da sua visão transcendente. As regras morais contidas no cristianismo são pressupostos para o alcance da vida eterna. Como é possível manter hábitos materialistas e de enaltecimento do corpo (e é por isso que a proposta de Compte-Sponville é ateia) aliada a uma moral cujo interesse final é a negação da vida em busca da salvação eterna? Desse modo, Onfray discorda da autenticidade do ateísmo de Comte-Sponville, já que conserva valores cristãos fundamentais.

\footnotetext{
${ }^{2}$ [...] pour défendre les valeurs des Lumières contre les propositions magiques, il faut promouvoir une laïcite post-chrétienne, à savoir athée, militante et radicalement opposée à tout choix de societé entre le judéochristianisme occidental et l'islam qui le combat. Ni la Bible, ni le Coran. Aux rabbins, aux prêtres, aux imams, ayatollahs et autres mollahs, je persiste à préferer le philosophe.
} 


\section{0 ateísmo espiritual de André Comte-Sponville}

Comte-Sponville aceita o título de "ateu cristão" (2006, p. 46), mas não se refere diretamente a Michel Onfray em nenhum momento em seu L'esprit de l'athéisme. Além disso, o sentido da expressão não é exatamente o que Onfray lhe confere. Comte-Sponville não aceita o cristianismo como religião, mas como tradição cultural. A partir dessa ideia e alguns outros elementos que serão brevemente apresentados a seguir, Comte-Sponville propõe um ateísmo bem diferente do de Onfray, o que permite uma comparação bastante instigante e reveladora do sentido do ateísmo contemporâneo, pois há também várias concordâncias.

$\mathrm{O}$ ateísmo de Comte-Sponville pode ser resumido a quatro pontos, dois negativos e dois positivos, aparentemente difíceis de conciliar. Em termos negativos, ele se declara ateu porque entende que as religiões são desnecessárias (2006, p. 77) e que Deus não existe (2006, p. 86). No entanto, positivamente, ele declara serem imprescindíveis a comunhão e a fidelidade, historicamente possibilitadas pela religião, e sustenta que o ateísmo não implica deixar de viver uma espiritualidade, pois esta é o que nos faz mais tipicamente seres humanos. O interesse de sua proposta está exatamente no modo como ele concilia seus lados positivos e negativos.

Definir uma religião é algo bem mais difícil do que parece, comenta ComteSponville (2006, p. 14). Por isso, é imprudente considerar que existam significados capazes de englobar todas as diferentes religiões do mundo. Nesse aspecto, ele parece ser mais cauteloso que Onfray, na medida em que este último pretende uma crítica totalizante da religião, sem se preocupar em definir o que é esse fenômeno.

Comte-Sponville se baseia no conceito apresentado por Émile Durkheim nas Formes élémentaires de la vie religieuse (1912). Religião é, então, definida como um conjunto de crenças e ritos que fazem referência a uma suposta realidade sagrada transcendente e que dá unidade a um grupo social, que se torna, assim, uma comunidade (COMTE-SPONVILLE, 2006, p. 16). Para Comte-Sponville, não há por que aceitar a noção de sagrado transcendente como realidade substantiva, pois a natureza imanente é suficiente. No entanto, é preciso preservar o espírito de fidelidade a uma comunidade social e a comunhão, imprescindíveis a qualquer sociedade. 
Em outras palavras, a religião foi historicamente capaz de forjar unidade social em torno de valores e regras morais e culturais, que permitiram ao ser humano se distinguir das outras espécies animais, que permitiram ao ser humano ser o que ele é. Porém, para ComteSponville, é possível a comunhão social e a fidelidade a valores e normas morais e culturais sem a referência a ditas realidades transcendentes, particularmente, sem referência a um Deus pessoal, tal como postulado pelo monoteísmo.

Assim, seja entendida como religare (religação), seja como relegere (releitura, acolhimento), a religião mostra algo do qual não podemos abrir mão e, ao mesmo tempo, ela não é imprescindível para cumprir esse papel. Tal com classicamente abordado por Durkheim, um dos principais papéis desempenhados pela religião é a resposta à desorganização social e existencial provocada pela morte. As crenças numa vida após a morte e num Deus salvador e os cultos correspondentes unificam a comunidade e a protegem da desordem. No entanto, segundo Comte-Sponville, já Epicuro ensinava que não há por que temer a morte, uma vez que não se sofre sem um corpo que sinta e não há o que temer senão a dor e, ao se morrer, o corpo deixa de sentir. Em outras palavras, o medo da morte pode ser superado pela razão e não apenas pela religião. Além disso, é muito mais sábio viver o presente e não a imaginária esperança numa vida eterna. $\mathrm{O}$ ateísmo permite despreocupar-se com essa ideia metafísica do porvir e, também com a ajuda da razão, suportar e consolar-se frente à dor da perda de um ente querido.

No entanto, o que Onfray define como "bestiário mitológico", Comte-Sponville qualifica como recurso importante do monoteísmo para a unidade social e manutenção da ordem diante de fatores desagregadores como a morte. Certamente, não seria tão fácil substituir, em pouco tempo, mais de dois mil anos de história.

Mesmo assim, é possível ter os resultados positivos oferecidos pelo monoteísmo sem adotar sua metafísica. Comte-Sponville identifica em algumas religiões do oriente como o Confucionismo, o Taoísmo e o Budismo fontes de inspiração para a edificação de imensas sociedades que duram até hoje. Nenhuma delas, segundo ele, reconhece a existência de um Deus transcendente. O que o autor procura mostrar é a chance de serem desenvolvidas práticas sociais que atendam ao interesse da coletividade, semelhantes àquilo que essas religiões já fazem. Valores como a comunhão, a disciplina e o respeito que devem ser estabelecidos, como melhor forma de vida possível. 
O monoteísmo, duramente criticado por Onfray, tem, entretanto, para ComteSponville enorme importância em nossa civilização, já que liga as pessoas entre si, conseguindo, por efeito, trazer a todos a sensação de estarem ao mesmo tempo ligados a Deus. Naturalmente, a ciência entende que tudo isso não passa de um fenômeno humano, compreendido mais facilmente pelos domínios da psicologia, história e sociologia. Porém, jamais um fenômeno dessas proporções poderia ser rotulado de maneira tão pejorativa, como está compreendido na filosofia de Onfray. A tese sponvilleana acrescenta que, para a ciência, o que liga os crentes entre si não é na verdade um Deus, pois sua existência ainda se mantém duvidosa, mas sim o fato de todos serem capazes de comungar da mesma fé: "Não há sociedade sem ligação: não há sociedade sem comunhão. Isso não prova que toda comunhão, nem, portanto, toda sociedade necessita da crença em um Deus pessoal e criador, nem mesmo de forças transcendentes e sobrenaturais." (COMTE-SPONVILLE, 2006, p. 29$)^{3}$

No ateísmo de Comte-Sponville, não só é possível comunhão e fidelidade sem religião, mas também espiritualidade sem Deus. Diferentemente de Onfray, ComteSponville se dispõe a apresentar argumentos para sua descrença em Deus, definindo-o de modo preciso (outra coisa que Onfray não se preocupa muito em fazer) como um ser pessoal, mas incorpóreo, transcendente, no sentido de ser superior e exterior à natureza, que seria onipotente, onisciente, eterno, infinitamente bom e criador do universo (COMTESPONVILLE, 2006, p. 80). Nada além da definição clássica do teísmo metafísico.

Exatamente por se tratar de metafísica, Comte-Sponville admite que não seja possível saber que Deus não existe, mas apenas crer nisso (2006, p. 84). O ateísmo, para ele, é uma crença tanto quanto o teísmo, mas uma crença para a qual podem ser oferecidas boas razões, a seu ver. Por um lado, faltam razões para se crer em Deus. As chamadas "provas da existência de Deus" não são decisivas, pois não levam necessariamente à conclusão de que Deus existe. Embora isso não assegure ao ateu uma razão para a descrença, trata-se de algo embaraçoso para o crente, pois é quem afirma que deve mostrar razões para crer (COMTE-SPONVILLE, 2006, p. 105). Além disso, faltam experiências que nos levem a crer que Deus existe com a mesma obviedade que cremos que existem os

\footnotetext{
${ }^{3}$ Pas de société sans lien: pas de société sans communion. Cela ne prouve pas que toute communion, ni donce toute société, nécessite la croyance en un Dieu personnel et créateur, ni même en des forces transcendantes ou surnaturelles.
} 
objetos diretamente acessíveis a nossa percepção. Se Deus existe, por que ele não aparece para todos? pergunta Comte-Sponville (2006, p. 106). Após criticar todos os argumentos apresentados em favor do Deus absconditus, o filósofo francês apresenta o terceiro argumento quanto à insuficiência da crença em Deus: o fato de que é uma explicação incompreensível, muito mais incompreensível do que os fenômenos que se pretende que se explique com esse conceito: "o universo já é um mistério suficiente. Para que teríamos necessidade de inventar outro?"4 (2006, p. 116). O teísmo acaba ficando entre um antropomorfismo intelectualmente inaceitável e um silêncio diante do incompreensível, que já poderia ser feito diante do próprio universo.

Por outro lado, argumenta Comte-Sponville, há razões positivas para se descrer no Deus definido acima. A primeira razão é bastante conhecida: o excesso de mal. Não há razão para um Deus infinitamente bom, poderoso e sábio permitir o mal. Uma visão naturalista conjugada ao darwinismo, porém, entende facilmente o mal, seja ele natural ou moral. As respostas classicamente apresentadas ao problema do mal são claramente insuficientes e não convencem. A segunda razão está na mediocridade do ser humano, algo também facilmente compreensível pelo naturalismo darwinista. Se formos à imagem e semelhança de Deus, então, os incontáveis defeitos humanos são boa razão para pensar que um Deus perfeito não pode existir. Por fim, o fato de que seria muito bom que Deus existisse, que isso satisfaria muito nossos desejos, é uma boa razão para desconfiar de que essa ideia não passa de um produto de nossa vontade, uma ilusão, no sentido freudiano do termo (COMTE-SPONVILLE, 2006, p. 139).

Entretanto, o fato de não acreditar em Deus, segundo Comte-Sponville, não significa abdicar de viver a espiritualidade, a parte ou função mais alta do ser humano (p. 145). O espírito é a função, a capacidade humana de pensar, querer, amar e sentir conscientemente. Nesse sentido, a espiritualidade é uma experiência e não uma teoria na qual se crê. É por essa razão, diz o filósofo francês, que é possível viver uma espiritualidade sem Deus.

Trata-se da experiência do absoluto, entendido não como um ser transcendente à natureza, mas como o conjunto de todas as condições do que é, ou seja, como a natureza mesma. O espírito é um resultado da natureza e faz parte dela. A espiritualidade é a

\footnotetext{
${ }^{4}$ L'univers fait um mystère suffisant. Pourquoi faudrait-il en inventer un autre?
} 
experiência dessa mesma natureza, do ser mesmo, para além da banalidade dos entes (COMTE-SPONVILLE, 2006, p. 153). Trata-se da experiência da imensidão da natureza, para além da prisão do eu; da experiência da unidade do universo como a única realidade que há; experiência do inefável e misterioso, ao mesmo tempo que imanente; experiência da simplicidade que dilui a ilusão egocêntrica que separa o eu interior do mundo exterior; experiência da eternidade como vivência do aqui e do agora; experiência da aceitação das coisas como são, como suspensão dos juízos de valor em termos absolutistas; experiência da liberdade por não se ter nem Deus nem mestre. Assim, Comte-Sponville propõe um "misticismo ateu", aberto a uma experiência direta do todo universal e que não deixa lugar para crença num Deus transcendente:

Ele vê. Que necessidade ele tem de dogmas?

Tudo está lá. Que necessidade ele tem de esperar?

Ele mora na eternidade. Que necessidade ele tem de aguardá-la?

Ele já está salvo. Que necessidade ele tem de uma religião? ${ }^{5}$ (COMTESPONVILLE, 2006, p. 202).

Fortemente inspirada no pensamento de Spinoza, o ateísmo de Comte-Sponville entende que não é preciso renunciar à espiritualidade ao se negar a religião e a crença num Deus pessoal.

\section{Breve comparação crítica entre os ateísmos de Onfray e Comte-Sponville}

Uma primeira ideia interessante revelada pelo estudo comparativo desses dois autores é que o ateísmo irreligioso moderno é um fenômeno muito mais complexo e multifacetado do que parecia a princípio. Além do ateísmo clássico apontado no início (que critica uma noção de deus em vista de uma concepção mais adequada de Deus), o ateísmo que estritamente nega Deus e a religião pode ter variações que as posições de Onfray e Comte-Sponville exprimem bem. Onfray opta por um ateísmo estrito sem concessões, para evitar o risco da incoerência. Comte-Sponville tenta aproveitar o que há de positivo nas tradições religiosas, para evitar o risco do empobrecimento existencial e cultural.

\footnotetext{
${ }^{5}$ Il voit. Qu'a-t-il besoin de dogmes? Tout est là. Qu'a-t-il besoin d'esperer? Il habite l'éternité. Qu'a-t-il besoin de l'attendre? Il est dejà sauvé. Qu'a-t-il besoin d'une religion?
} 
Salta aos olhos o estilo agressivo de Onfray. Conforme indicado acima, seu propósito é reagir, o mais energicamente possível, a uma desastrosa retomada da religião no início do século XXI. Sua crítica à religião é impiedosa e sua proposta é erradicá-la para o bem da humanidade. A vacina para a erradicação desse "vírus" ${ }^{6}$ seria a razão. Quais os males da religião? Obscurantismo, violência, intolerância, entre outros. Uma pergunta óbvia que surge diante da leitura de Onfray é se ele não estaria sendo intolerante também, e se sua crítica generalizada e em bases pretensamente científicas (fortemente criticáveis, porque apresentadas com escassa fundamentação em pesquisa metodologicamente sólida) não seria também uma forma de violência desrespeitosa e obscurantista.

O tom raivoso e militante do livro de Onfray desperta uma forte desconfiança inicial de que há ali pouco valor filosófico e científico. A desconfiança inicial se confirma amplamente no decorrer da leitura. A imputação ao monoteísmo dos males principais que há no mundo beira o ridículo, e as críticas aos elementos da fé judaica, cristã e islâmica são de uma superficialidade impressionante. É uma pena que respostas muito bem argumentadas contra o Traité d'athéologie, tal com as formuladas por Irène Fernandez (2005) e Matthieu Baumier (2005) não tenham tido a mesma repercussão que o livro de Onfray. A popularidade de uma obra tão criticável quanto a de Onfray faz pensar no quão lamentavelmente forte é o gosto popular pela teoria da conspiração e pela demonização fácil. Por outro lado, é possível que sua alta vendagem se explique também por uma clara aversão, em certos círculos culturais, ao fenômeno religioso, embora o conteúdo da ateologia de Onfray acabe se mostrando, mesmo que na direção oposta, aquilo que de pior é imputado à religião: o irracionalismo e a intolerância. Michel Onfray tem o mérito de ser o porta-voz de uma significativa insatisfação com o que há de pouca inteligência, desrespeito à diferença e perversidade política na atividade religiosa. Uma insatisfação que precisa ser levada a sério, mas que parece ter pouca sustentação e resposta na análise e na proposta de Onfray.

É porque representa uma legítima resposta às crenças e práticas religiosas que seria uma pena se o ateísmo filosófico contemporâneo tivesse apenas Onfray. Felizmente,

\footnotetext{
${ }^{6}$ Richard Dawkins (2006), outro forte defensor do ateísmo estrito, usa exatamente esse termo ao se referir à religião.
} 
Comte-Sponville representa, na filosofia francesa atual, uma alternativa bem mais fundamentada e respeitável em termos argumentativos.

A proposta de Comte-Sponville tem elementos de originalidade e de continuação de uma tradição filosófica de ateísmo que aos poucos vai se firmando. Tal como Onfray, embora de maneira bem mais sólida, Comte-Sponville defende uma posição materialista e naturalista. Diferentemente de seu compatriota, porém, o autor de L'esprit de l'athéisme não rejeita a religião em sua totalidade nem a acusa de todos os males que há. Enquanto criadora de vínculo social e de valores humanos, a religião teria prestado grandes serviços à humanidade e provavelmente ainda o fará. No entanto, não só pelo seu caráter emancipador (COMTE-SPONVILLE, 2006, p. 18), mas, sobretudo, porque não há necessidade de se postular qualquer realidade sobrenatural, para Comte-Sponville, é melhor se buscar uma base não-religiosa para o vínculo social e a espiritualidade.

Apesar dos argumentos de Comte-Sponville em prol da inexistência de Deus estarem bem apresentados, há boas respostas a cada um deles, tal como ele mesmo reconhece a possibilidade. No entanto, é mais interessante questionar aqui dois pontos centrais de sua proposta positiva: o naturalismo e a espiritualidade ateia.

Comte-Sponville propõe, como concepção metafísica alternativa ao teísmo, o naturalismo, entendido como a tese de que não há nada além da natureza. O conceito não é muito fácil de entender, porém. Segundo ele, a natureza seria o conjunto de todas as condições e compreende toda a realidade, o que exclui o sobrenatural, que não existe (COMTE-SPONVILLE, 2006, p. 148). O espírito, segundo o filósofo francês, não tem independência ontológica em relação à natureza, mas faz parte dela, é um produto dela. Citando Spinoza, Comte-Sponville admite que a moral não existe na natureza, mas é real mesmo assim, pois bom e mal existem para nós apenas e não metafisicamente (COMTESPONVILLE, 2006, p. 189).

É provável que Comte-Sponville queira dizer com natureza o que C. S. Lewis chamou de "aquilo que acontece por si mesmo", "que existe por sua própria conta", o que não se dá por uma força ou ação externa, mas que é espontâneo e não-intencional (LEWIS, 2002 [1947], p. 7). O naturalista é aquele que acredita que o fato último, além do qual não há nada, é o conjunto total de coisas que acontecem por relação de causa e efeito no espaço e no tempo. Não há uma razão intencional guiando as coisas, não há um bem ao qual elas se 
dirigem. Consequentemente, o naturalista não pode aceitar a ideia de um Deus pessoal, que existe independentemente da natureza e que a criou, pois nada existe independentemente da natureza.

Um problema com o naturalismo, segundo aponta o próprio C. S. Lewis, entre outros autores, como Alvin Plantinga (2000) e Richard Taylor (1963), é que ele torna difícil entender ideias como racionalidade e verdade. Razões seriam acréscimos humanos na tentativa de compreender relações de causa e efeito entre eventos e seres do mundo. Porém, ter uma razão é diferente de ter uma causa e, comumente, não tenho razão de aceitar como verdadeira uma tese exatamente quando minha crença tem uma causa "material" (outro termo altamente problemático na teoria naturalista) que me levou a acreditar nela (por exemplo, a ação do meu inconsciente ou o efeito das relações de poder na sociedade em que vivo). Razões são modos de sustentar uma ideia em outra ideia, com base numa implicação lógica e não numa relação causal no espaço e tempo.

Se, tal como propõe a perspectiva naturalista e materialista do ateísmo de ComteSponville, razão e verdade são acréscimos humanos a fatos do mundo e se o ser humano é apenas uma espécie biológica que surgiu devido a causas ligadas à adaptação ao meio sem qualquer intenção que a guiasse, por que razão aceitar que o ser humano é capaz de conhecer o mundo? Em outras palavras, segundo o naturalismo, razão e verdade estão no mundo apenas devido ao desenvolvimento da espécie humana, que se originou, como qualquer espécie, devido a causas ligadas não ao conhecimento da verdade, mas à sobrevivência do mais apto. Na concepção naturalista, o conhecimento não tem primazia, pois ele apenas cumpre a função de ajudar na sobrevivência e reprodução da espécie humana. Mas se o aparato cognitivo humano é apenas mais um modo de assegurar nossa sobrevivência e reprodução, por que confiar que ele dá de fato informações verdadeiras? Por que aceitar que são verdadeiras teses como a do naturalismo, por exemplo?

É preciso lembrar que a natureza em si mesma é algo inteiramente fora de qualquer possibilidade de experiência. É com base numa inferência, com base na razão, que se chega à ideia de natureza e é pretensamente fundamentado em razões que o naturalista pretende excluir Deus da totalidade do real. Mas o naturalismo parece retirar o fundamento de seu próprio argumento ao privilegiar relações de causa e efeito e tentar derivar dessas relações aquilo que podemos chamar de racionalidade e verdade. O próprio naturalismo faz pensar 
que não há razão para aceitá-lo como tese. Se for assim, então o naturalismo tem um defeito muito maior do que o teísmo, pois, em termos argumentativos, é muito pior para uma ideia ser incoerente e auto-refutadora do que ser problemática. Nesse caso, Michel Onfray estava certo ao dizer que o ateísmo cristão de Comte-Sponville era incoerente, embora sua razão para concluir isso fosse bem diferente, pois, tanto quanto seu compatriota, Onfray é também um naturalista.

Outro problema do naturalismo refere-se à moralidade. Se entendermos o âmbito moral como dizendo respeito ao que deve ser feito, e não aos fatos que são, mas sim à conduta racionalmente justificada na promoção de um bem, então parece haver uma incompatibilidade entre a ética e a noção de que a realidade se reduz à natureza. Em geral, entende-se que uma boa conduta independe e, frequentemente, até contraria impulsos naturais. Se a natureza é a realidade fundamental, então a conduta moralmente correta será não apenas algo para além da natureza, mas, por vezes, antinatural. Os cínicos antigos e hedonistas como Onfray não teriam problema nenhum em concordar com essa tese. $\mathrm{O}$ problema é que abrir mão da moralidade, da possibilidade de avaliar como mau um comportamento, ainda que ele seja explicável em termos naturais ou mesmo que se dê conforme a natureza em geral, é abrir mão do que há de mais nobre no ser humano, como dizia, por exemplo, Charles Darwin (DARWIN, 2004 [1879], p. 159).

Ao criticarem o "falso moralismo burguês", freudianos e marxistas tentam "desmascarar" pretensões de alto padrão de moralidade que escondem, na verdade, interesses político-econômicos ou de motivação sexual. Em outras palavras, tentam mostrar que são causas materiais ou naturais que estão por trás de supostas avaliações éticas. Mesmo sendo críticas a padrões morais estabelecidos, essas análises corroboram a tese de que a moralidade - sendo ela concretamente possível ou não - é algo que está num plano diferente da natureza. Comte-Sponville admite isso e tenta resolver essa aparente exceção ao naturalismo com a tese de que os valores éticos não são absolutos, o que o coloca na popular companhia dos relativistas morais, que parecem ter uma posição tão simpática e tolerante. O problema é que uma coisa é o conteúdo das avaliações morais, que pode variar na história e de cultura para cultura, outra coisa é a própria possibilidade de avaliação moral, a própria moralidade, que não é relativa, mas condição de nossa humanidade. Nesse sentido, o naturalismo, como metafísica que exclui tudo que não é natural, não seria só 
auto-refutador e incoerente, ele seria também incompatível com aquilo que temos de mais humano.

Um último problema que seria interessante apontar no ateísmo cristão de ComteSponville é que a espiritualidade que ele propõe parece pouco coerente com a ideia de comunhão e unidade social que ele também propõe. É verdade que muitas sociedades puderam forjar esses elementos sem precisar explicitamente da crença num Deus pessoal. No entanto, não parece exato dizer que tais culturas eram ateias no sentido irreligioso e de negação de toda transcendência, tal como postula Comte-Sponville. Em todo caso, a espiritualidade proposta por ele, mesmo com frequentes referências a místicos orientais, tem uma diferença significativa em relação à proposta espiritual de um budismo, um hinduísmo ou um confucionismo. Provavelmente devido ao fato de que se baseia numa concepção fundada no individualismo epistemológico do iluminismo (o "ousa pensar por ti mesmo" supõe que se chega melhor ao conhecimento quando se vai sozinho ao invés de se seguir a opinião comum ou uma autoridade estabelecida) e na afirmação do sujeito individual própria da modernidade ocidental, a espiritualidade de Comte-Sponville não é para ser vivida coletivamente, mas de modo solitário. Místicos são geralmente solitários em suas experiências religiosas, mas eles são exceções nas tradições a que pertencem. Além disso, nas grandes tradições religiosas, os místicos geralmente se conformam a critérios comunitariamente estabelecidos para avaliar se sua experiência mística é autêntica ${ }^{7}$. Diferentemente da espiritualidade monoteísta que ele critica, o misticismo ateu de ComteSponville parece não deixar lugar para a ligação e a comunhão que ele entende serem contribuições positivas das religiões para a vida social.

\section{Conclusão}

Em suma, podemos dizer que Michel Onfray e André Comte-Sponville são dois continuadores de uma tradição na filosofia francesa, iniciada no século XVIII, de negação do conceito monoteísta de Deus aliada a uma rejeição de toda e qualquer prática religiosa. Onfray representa um ateísmo mais militante, que se preocupa em combater o elemento

\footnotetext{
${ }^{7}$ A dimensão social da experiência religiosa é exemplarmente discutida em Perceiving God de William Alston (1991).
} 
culturalmente pernicioso e politicamente destrutivo da religião. O problema é que sua defesa da tolerância e de critérios racionais e argumentativos como uma alternativa ao obscurantismo e intolerância religiosos não parece coerente com seu próprio trabalho, que é um violento repúdio à religião, com pouca base em argumentos. Comte-Sponville adota uma posição mais conciliadora e fundamentada, embora também siga a linha geral de negação da religião e do conceito de Deus, sugerindo uma espiritualidade ateia e uma atitude de "comunhão e fidelidade" forjadoras de vínculo social, que reconhece o papel central desempenhado pelo cristianismo na tradição cultural do ocidente. Sua proposta de misticismo ateu, porém, acaba sendo basicamente individualista, não ensejando qualquer vínculo social a partir de sua vivência. Além disso, o naturalismo que Comte-Sponville propõe como alternativa à metafísica teísta parece não só ser auto-refutador, mas também tornar bastante difícil qualquer noção de moralidade.

É possível que haja boas respostas a essas observações críticas. Afinal, o ateísmo filosófico estrito é uma proposta ainda muito recente e que vem aparentemente ganhando adeptos, haja vista o sucesso editorial de seus autores. No entanto, nunca é demais lembrar que aquele que critica (e o ateísmo moderno se mostra, antes de tudo como um iconoclasta, quase à la lettre) pode também ser criticado. Nada mais saudável para o debate filosófico.

\section{Referências}

ALSTON, William. Perceiving God - The Epistemology of Religious Experience. Ithaca/London: Cornell University Press, 1991.

BAUMIER, Matthieu. L'anti-traité d'athéologie - Le système Onfray mis a nu. Paris: Presses de la Renaissance, 2005.

COMTE-SPONVILLE, André. L'esprit de l'athéisme - Introduction à une spiritualité sans Dieu. Paris: Albin Michel, 2006.

DARWIN, Charles. The Descent of Man, and Selection in Relation to Sex - Second Edition. London: Penguin Books, 2004 [1879].

DAWKINS, Richard. The God Delusion. Boston/New York: Houghton Mifflin Company, 2006.

FERNANDEZ, I. Dieu avec esprit: Réponse à Michel Onfray. Paris: Philippe Rey, 2005. 
LEWIS, C. S. Miracles - A Preliminary Study. London: Harper Collins, 2002 [1947].

ONFRAY, Michel. Traité d'athéologie - Physique de la Métaphysique. Paris: Grasset \& Fasquelle, 2005.

PLANTINGA, Alvin. Warranted Christian Belief. New York/Oxford: OUP, 2000.

TAYLOR, Richard. Metaphysics. New York: Prentice-Hall, 1963. 